\title{
PENDIDIKAN MATEMATIKA DI ERA REVOLUSI INDUSTRI 4.0
}

\author{
Muhammad Darwis M. \\ Dosen Jurusan Matematika FMIPA UNM Makassar \\ Email: darwismath2011@yahoo.com ataudarwismath2018@gmail.com
}

\begin{abstract}
Abstrak. Saat ini kita berada pada era Revolusi Industri 4.0. Sebagaimana diketahui bahwa tiap era Revolusi Industri memiliki peluang dan ancaman, maka era Revolusi Industri 4.0 ini pun demikian. Era Revolusi Industri 4.0 disebut juga era globalisasi. Bagi Indonesia khususnya, masyarakat harus mampu membaca dan responsif terhadap perubahan dan membekali diri dengan keterampilan terkini agar bisa bersaing. Di era ini, realitas menunjukkan bahwa teknologi dan pembelajaran matematika memiliki kaitan erat. Pemanfaatan teknologi dengan baik dalam pembelajaran akan memberi penguatan terhadap pola perubahan paradigma pembelajaran. Sifat abstrak objek kajian matematika yang sulit dipikirkan oleh peserta didik dapat dipresentasikan melalui simulasi komputer agar lebih konkrit. Latihan dan percobaan eksploratif matematika dapat dilakukan peserta didik dengan menggunakan program komputer atau software matematika untuk penanaman dan penguatan konsep, membuat pemodelan matematika, dan menyusun strategi dalam memecahkan masalah. Oleh karena itu, guru matematika dituntut agar seirama dengan perkembangan di era ini.
\end{abstract}

Kata kunci: Pendidikan . Matematika . Revolusi Industri 4.0

\section{A. Sekilas tentang Revolusi Industri 4.0}

Istilah Revolusi Industri 4.0 adalah istilah yang menunjuk kepada Revolusi Industri yang ke empat. Berdasarkan laporan dari Davies yang dikutip oleh Prasetyo \& Sutopo (2017), diketahui bahwa telah terjadi empat kali Revolusi Industri. Revolusi Industri pertama terjadi pada akhir abad ke-18 yaitu tahun 1784 di Inggris. Penanda revolusi di masa itu adalah penemuan mesin uap dan sebagian pekerjaan manusia mulai digantikan oleh mesin. Revolusi yang kedua terjadi pada akhir abad ke-19. Penanda revolusi ini adalah penggunaan mesin produksi bertenaga listrik untuk memproduksi secara massal. Revolusi Industri yang ketiga terjadi pada awal abad ke-20 yaitu tahun 1970. Penanda revolusi ini adalah penggunaan teknologi komputer untuk memproduksi secara otomatis.

Pekerjaan manusia digantikan oleh mesin (mekanisasi) adalah satu revolusi yang disebut Revolusi Industri 1.0. Kemudian penemuan listrik dan penggunaannya untuk melakukan mekanisasi produksi massal juga adalah satu revolusi yang disebut Revolusi Industri 2.0. Berikutnya, mekanisasi produksi massal dengan alat listrik yang dikontrol dengan teknologi komputer (komputerisasi) pun adalah satu revolusi yang disebut Revolusi Industri 3.0. Saat ini, terjadi perkembangan pesat dalam bidang teknologi, sehingga bukan hanya teknologi komputer, tapi juga teknologi sensor, interkoneksi, dan analisis data. Inilah yang disebut sebagai Revolusi Industri 4.0.

\section{B. Ragam Persoalan di Era Revolusi Industri 4.0}

Faktor kunci terjadinya Revolusi Industri adalah revolusi ilmu pengetahuan yang seiring dengan keinginan manusia melakukan inovasi. Sejak revolusi industri pertama, telah muncul banyak ilmuwan yang mengembangkan ilmu pengetahuan dengan melakukan riset. Hingga akhirnya sampai pada revolusi industri 4.0 dengan peluang atau potensi manfaat 
yang luar biasa. Prasetyo \& Sutopo (2018) menyebutkan peluang atau potensi manfaat tersebut adalah sebagai berikut.

a. Pengembangan produk menjadi lebih cepat, mewujudkan permintaan yang bersifat individual (kustomisasi produk), produksi yang bersifat fleksibel dan cepat dalam menanggapi masalah serta efisiensi sumber daya.

b. Perbaikan produktivitas, mendorong pertumbuhan pendapatan, peningkatan kebutuhan tenaga kerja terampil, peningkatan investasi.

c. Terwujudnya kustomisasi massal dari produk, pemanfaatan data kosong (idle) dan perbaikan waktu produksi.

d. Mampu memenuhi kebutuhan pelanggan secara individu, proses rekayasa dan bisnis menjadi dinamis, pengambilan keputusan menjadi lebih optimal, melahirkan model bisnis baru dan cara baru dalam mengkreasi nilai tambah.

e. Mewujudkan proses manufaktur yang efisien, cerdas dan on-demand (dapat dikostumisasi) dengan biaya yang layak.

Sayangnya Revolusi Industri 4.0 sebagai bagian dari buah revolusi ilmu pengetahuan menimbulkan masalah-masalah baru. Masalah-masalah tersebut dapat kita lihat dalam konteks kemanusiaan, negara, sosial, dan pendidikan.

Dalam konteks kemanusiaan, masalahnya adalah pada mekanisasi kerja. Peluang yang telah disebutkan di atas menunjukkan bahwa dalam masyarakat modern yang berteknologi tinggi seperti itu, manusia menghadapi mekanisasi kerja. Alat-alat produksi baru dihasilkan oleh teknologi modern dengan proses mekanisasi, otomatisasi, dan standarisasi. Semua itu menyebabkan manusia cenderung menjadi elemen yang mati dari proses produksi. Teknologi modern yang sesungguhnya diciptakan untuk pembebasan manusia dari kerja nyata telah menjadi alat perbudakan baru. Ketika manusia menjadi bagian dari logika produksi teknologi modern, ia hanya menjadi elemen mekanisasi, dan elemen otomatisasi teknologi. Ia berubah menjadi sekadar suatu faktor dari mesin, tak lain sebagai bagian dari mesin itu. Karena itulah, manusia di zaman modern ini menjadi terbelenggu oleh proses teknologi. Singkatnya, ia cenderung memperbudak manusia, sebab manusia sekadar menjadi otomat dari proses produksi, memperbudak masyarakat untuk mengonsumsi kebutuhan-kebutuhan semu yang diproduksi oleh mesin-mesin itu. (Kuntowijoyo, 2006).

Dalam konteks negara, era Revolusi Industri 4.0 juga melahirkan tantangan. Drath \& Horch (2014) berpendapat bahwa tantangan yang dihadapi oleh suatu negara ketika menerapkan Industri 4.0 adalah: (a) munculnya resistansi terhadap perubahan demografi dan aspek sosial, (b) ketidakstabilan kondisi politik, (c) keterbatasan sumber daya, (d) risiko bencana alam, dan (e) tuntutan penerapan teknologi yang ramah lingkungan.

Dalam konteks sosial, masyarakat kita saat ini juga tengah berkembang semangat individualisme, hedonisme, terorisme, dan bahkan separatisme. Ini melanda hampir semua komponen bangsa, baik muda maupun tua, rakyat biasa, maupun pejabat negara termasuk kalangan anggota dewan. Bila kita menganggap bahwa angkatan 45 sebagai generasi pejuang, angkatan 66 sebagai generasi pembangun, maka angkatan 98 sampai saat ini adalah generasi penikmat sekaligus penghancur (Iswan \& Herwina, 2018).

Dalam konteks pendidikan, ada ancaman yang disebut sebagai disrupsi pendidikan. Teman sebaya dan gadget yang menghubungkan sang anak pada dunia maya adalah dua kekuatan yang mempengaruhi kepribadian seorang anak. Tidak efektifnya peran keluarga, sekolah, dan masyarakat sebagai tri pusat pendidikan adalah karena munculnya kekuatan budaya baru dalam sebuah layanan edukasi yang tak terbatas terkemas dalam gadget dan 
bebasnya persahabatan teman sebaya. Oleh karena itu, era disrupsi disebut juga era tumbangnya kesakralan keluarga, sekolah dan masyarakat karena terhempas oleh datangnya kekuatan baru dalam bentuk yang tak terlihat dan bisa hadir di manapun seorang anak berada. Dengan demikian, seorang anak telah menjadi pasar baru dari kuatnya produksi informasi dari dunia maya. Seorang anak juga telah menjadi pasar dunia maya yang sajiannya bebas tak terbatas. Mereka seolah hanya tinggal dalam dua dimensi yang menyenangkan bagi mereka, yakni dunia maya dan sebaya. Oleh karena itu, pendidikan harus tampil menjalankan perannya dengan baik agar ancaman di era Revolusi Industri 4.0 bisa diminimalkan atau dihilangkan, sehingga akan memaksimalkan peluang di era ini. Atau jika tidak, maka ancaman itu yang justru akan terus berkembang dan kian menyulitkan mendapatkan peluang di era ini.

\section{Peran Pendidikan dalam Menghadapi Era Revolusi Industri 4.0}

Undang-Undang No.20 tahun 2003 tentang Sistem Pendidikan Nasional Pasal 1 ayat 1 dan 2 berbicara tentang pendidikan dan pendidikan nasional. Pada ayat 1 disebutkan, "Pendidikan adalah usaha sadar dan terencana untuk mewujudkan suasana belajar dan proses pembelajaran agar peserta didik secara aktif mengembangkan potensi dirinya untuk memiliki kekuatan spiritual keagamaan, pengendalian diri, kepribadian, kecerdasan, akhlak mulia, serta keterampilan yang diperlukan dirinya, masyarakat, bangsa dan negara." Adapun pada ayat 2, "Pendidikan nasional adalah pendidikan yang berdasarkan Pancasila dan Undang-Undang Dasar Negara Republik Indonesia Tahun 1945 yang berakar pada nilai-nilai agama, kebudayaan nasional Indonesia dan tanggap terhadap tuntutan perubahan zaman."

Berdasarkan Undang-undang Sistem Pendidikan Nasional tersebut, pemerintah merespons era Revolusi Industri 4.0. Sebagai bentuk respons tersebut, pemerintah mengeluarkan kebijakan berupa revitalisasi pendidikan kejuruan Indonesia (Yahya, 2018). Inti dari revitalisasi ini ada pada gerakan literasi baru yang dicanangkan oleh pemerintah sebagai penguat untuk merespon era industri 4.0. Bahkan gerakan literasi baru ini menggeser gerakan literasi lama yang hanya fokus pada peningkatan kemampuan membaca, menulis, dan matematika. Gerakan literasi baru yang dimaksudkan terfokus pada tiga literasi utama, yaitu: 1) literasi digital, 2) literasi teknologi, dan 3) literasi manusia. Literasi digital, literasi teknologi, dan literasi manusia adalah tiga keterampilan yang diprediksi menjadi keterampilan yang sangat dibutuhkan di masa depan atau di era industri 4.0. Literasi digital diarahkan pada tujuan peningkatan kemampuan membaca, menganalisis, dan menggunakan informasi di dunia digital (big data). Literasi teknologi bertujuan untuk memberikan pemahaman pada cara kerja mesin dan aplikasi teknologi. Adapun literasi manusia diarahkan pada peningkatan kemampuan berkomunikasi dan penguasaan ilmu desain (Aoun, 2017).

Program revitalisasi pemerintah seharusnya berlandaskan pada Undang-undang Sistem Pendidikan Nasional No.20 tahun 2003. Pada ayat 1 undang-undang itu disebutkan, "Pendidikan adalah usaha sadar dan terencana untuk mewujudkan suasana belajar dan proses pembelajaran agar peserta didik secara aktif mengembangkan potensi dirinya untuk memiliki kekuatan spiritual keagamaan, pengendalian diri, kepribadian, kecerdasan, akhlak mulia, serta keterampilan yang diperlukan dirinya, masyarakat, bangsa dan negara." Kekuatan yang paling pertama seharusnya dimiliki oleh peserta didik setelah menempuh pendidikan adalah spiritual keagamaan. Ini dikuatkan oleh ayat 2 yang menyatakan bahwa akar pendidikan adalah nilai-nilai agama dan budaya nasional Indonesia. Secara tersirat dalam undang-undang ini disebutkan bahwa agama seharusnya menjadi fondasi program 
pendidikan, termasuk program revitalisasi pendidikan sebagai respons pemerintah terhadap era Revolusi Industri 4.0.

Nilai spiritual keagamaan tentu saja bertentangan dengan nilai Barat, di mana Revolusi Industri 4.0 ini digagas. Di dalam pemikiran Barat, hampir selalu kita temukan bahwa kemajuan dapat dicapai, hanya jika kita membebaskan diri dari alam pikiran agama. Itulah sebabnya, mereka kemudian meninggalkan kitab suci. Karena mereka mengesampingkan referensi transendentalnya itulah, sehingga mereka kehilangan petunjuk. Kita melihat bahwa ternyata mereka kemudian jatuh ke dalam bermacam-macam aliran pemikiran yang dengan itu mereka justru menjadi terbelenggu. Lihat saja misalnya di kalangan Marxisme. Mereka terpuruk dalam belenggu pemikiran mereka yang disebut determinisme. Dengan pandangan ini, mereka menganggap manusia tidak dapat merdeka, karena kesadarannya, keberadaan sosialnya, dan bahkan keberadaan eksistensialnya, ditentukan oleh posisi ekonomi, dan cara produksinya. Manusia dianggap tidak mempunyai orientasi transendental dan bahwa manusia hanyalah produk masyarakatnya. Formasi sosial masyarakatnyalah yang menentukan kesadarannya (Kuntowijoyo, 2006).

Sesungguhnya misi agama, sebut saja Islam misalnya, misi terbesarnya adalah pembebasan. Dalam konteks dunia modern, dapat diartikan bahwa agama harus membebaskan manusia dari kungkungan aliran pemikiran yang menganggap bahwa manusia tidak mempunyai kemerdekaan dan hidup dalam absurditas. Tapi, karena dunia modern juga telah menciptakan sistem-sistem yang membelenggu manusia, baik itu berupa sistem produksi teknologi modern, sistem sosial dan ekonomi, maupun sistem lainnya yang menyebabkan manusia tidak dapat mengaktualisasikan dirinya sebagai makhluk yang merdeka dan mulia. Agama harus tampil melakukan revolusi untuk merombak semua itu sebagai suatu wujud revolusi untuk pembebasan. Dengan visi teologis semacam ini, agama sesungguhnya menyediakan basis pemikiran untuk mengisi kehampaan spiritual yang merupakan produk dunia modern industrial. Sudah saatnya kini agama tampil kembali untuk memimpin peradaban dan menyelamatkan manusia dari belenggu dunia modern (Kuntowijoyo, 2006).

Cara pembebasan manusia dari belenggu teknologi disebutkan dalam Al-Qur'an. Tuhan menyebutkan dalam Al-Qur'an bahwa manusia dapat mencapai kemajuan, kemuliaan, dan kejayaan, jika ia mau membersihkan dirinya sendiri secara terus menerus. Jadi, manusia pada esensinya bukan hanya bersifat mulia, tapi juga ia dapat mencapai kemuliaan yang lebih tinggi, apabila ia membersihkan dirinya secara terus-menerus. Kita mengenal berbagai cara untuk mencapai kemajuan dengan jalan pembersihan itu, misalnya dengan senantiasa bersyukur dan bersabar. Dengan cara itulah, kemajuan material yang kita capai tidak akan menjadikan kita gelisah, khawatir, teralienasi, atau menjadikan kita ingkar. Ini karena cita-cita Al-Qur'an mengenai kemajuan manusia sesungguhnya bersifat spiritual, yaitu untuk mencapai ridha Allah. Apapun usaha manusia di dunia harus selalu dikaitkan dengan tugasnya sebagai khalifah Allah untuk menguasai dan mengatur dunia ini agar sesuai dengan kehendak-Nya (Kuntowijoyo, 2006).

\section{Keterkaitan antara Teknologi dan Pembelajaran Matematika}

Teknologi dan pembelajaran matematika memiliki kaitan erat, terlebih di era Revolusi Industri 4.0. Pemanfaatan teknologi dengan baik dalam pembelajaran akan memberi penguatan terhadap pola perubahan paradigma pembelajaran. Penggunaan teknologi adalah salah satu cara yang efektif dan efisien dalam menyampaikan informasi kepada peserta didik. Komputer merupakan salah satu teknologi yang berpotensi besar meningkatkan kualitas pembelajaran matematika. Sifat abstrak objek kajian matematika 
yang sulit dipikirkan oleh peserta didik dapat dipresentasikan melalui simulasi komputer agar lebih konkrit. Latihan dan percobaan eksploratif matematika dapat dilakukan peserta didik dengan menggunakan program komputer atau software matematika untuk penanaman dan penguatan konsep, membuat pemodelan matematika, dan menyusun strategi dalam memecahkan masalah.

Beberapa software matematika yang dapat digunakan pada laptop maupun handphone antara lain: 1) Photomath. Photomath merupakan aplikasi Android yang dapat membantu menyelesaikan berbagai soal matematika yang kita hadapi, baik di sekolah maupun di bangku kuliah. Aplikasi ini bisa dibilang merupakan kalkulator berbasis kamera. Kamu cukup memotret soal matematika yang akan dikerjakan. Setelah itu, Photomath akan menampilkan jawabannya.
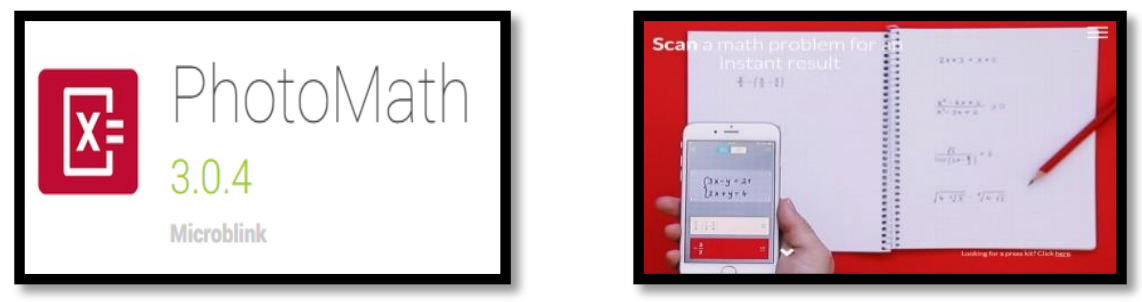

Gambar 1. Software PhotoMath

2) AutoMath Photo Calculator. AutoMath Photo Calculator mirip dengan Photomath. Cara menggunakannya juga sama. Kita hanya perlu mengarahkan kamera ke soal matematika dan memotretnya. AutoMath Photo Calculator pun akan menjawab soal matematika itu. Sayangnya, aplikasi ini masih belum bisa membaca soal yang ditulis tangan, tidak seperti Photomath. Kelebihan AutoMath Photo Calculator ada pada rumusrumus yang bisa membantu pengguna menyelesaikan berbagai soal matematika.
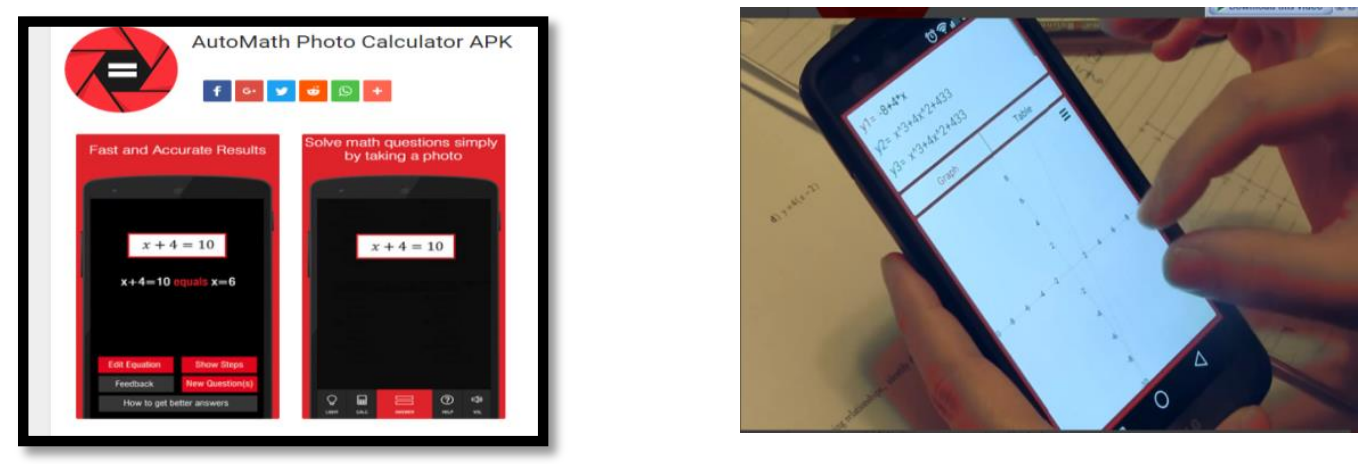

Gambar 2. AutoMath Photo Calculator

3) MatMath. MatMath merupakan aplikasi matematika dalam wujud kalkulator. Pengguna cukup memasukkan soal yang ingin dijawab melalui virtual keyboard yang tersedia. Sebelum memulai menggunakan MatMath, kita akan diberikan tutorial bagaimana cara menggunakannya. Aplikasi ini akan memberikan beberapa cara untuk menjawab 
sebuah pertanyaan, juga bisa melihat langkah demi langkah dalam menjawab soal matematika yang dimasukkan.

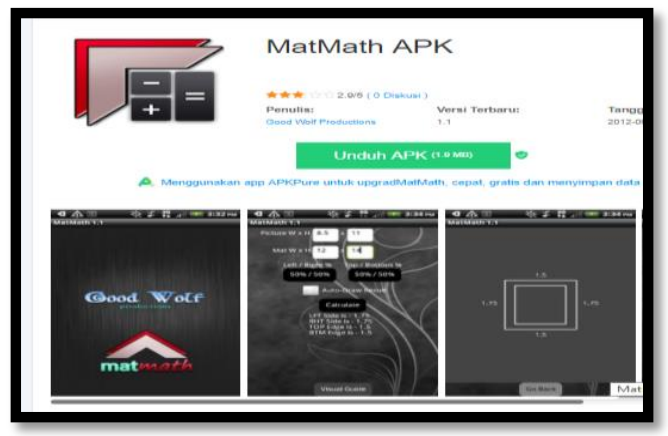

\section{Gambar 3. Software MatMath}

4) MathWay. Mathway merupakan aplikasi matematika yang cukup lengkap. Soal matematika dasar, algoritma, kalkulus, dan kimia dapat dipecahkan menggunakan aplikasi ini. Begitu membuka Mathway, kita akan dihadapkan pada virtual keyboard untuk memasukkan soal matematika di sisi bawah layar, serta jenis soal matematika beserta rumusnya di sisi atas. MathWay memiliki tampilan yang lebih sederhana dibanding dengan MatMath. Cara menggunakannya juga lebih mudah berkat adanya jenis soal matematika. Dengan begitu, rumus yang tidak ada kaitannya tak akan dimunculkan pada layar. Ada beberapa kekurangan pada aplikasi ini. Pengguna diharuskan mendaftar jika ingin melihat langkah demi langkah dalam menjawab soal matematika. Selain itu, fitur kamera kalkulator yang disematkan cukup sulit digunakan dibanding dengan Photomath atau Automath Photo Calculator.

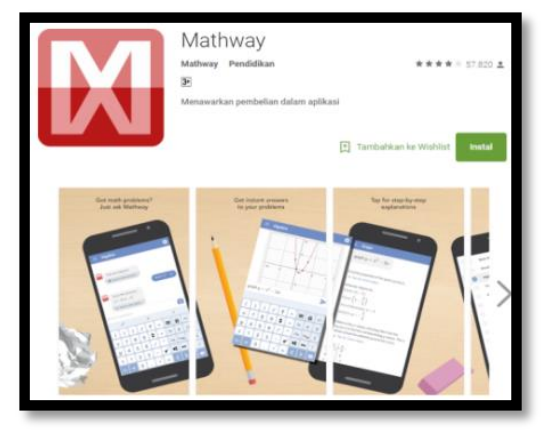

Gambar 4. Software Mathway

5) Math Expert. Math Expert merupakan aplikasi yang menyediakan berbagai rumus matematika, fisika, teknik elektro, kimia. Semuanya rumus diatur berdasarkan kategorinya, seperti rumus trigonometri pada kategori matematika, dan rumus massa pada kategori fisika. Pembagian ini juga memudahkan kita dalam menyelesaikan berbagai soal dengan mudah.Cukup mencari kategori soal yang ingin dipecahkan dan memasukkan angka-angka pada kolom yang telah disediakan. Setelah itu tap tombol Calculator untuk menemukan jawabannya.

Math Experts juga menyediakan fitur grafik untuk soal-soal tertentu. Sayangnya, aplikasi ini tidak menjabarkan langkah demi langkah dalam menyelesaikan soal. Pengguna hanya dapat melihat jawaban tanpa tahu proses memecahkan soalnya. 


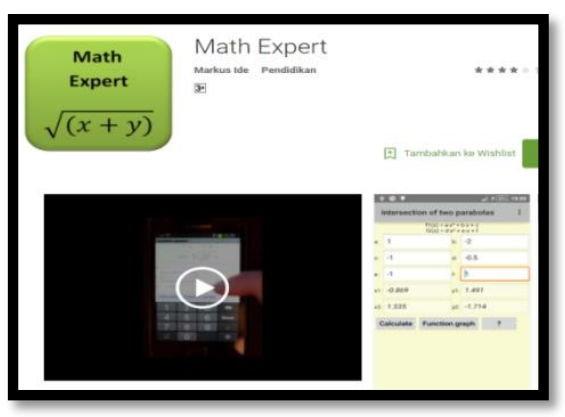

Gambar 5. Software Math Expert

6) MyScipt Calculator. MyScript Calculator adalah aplikasi yang menggunakan Android seperti selembar kertas untuk mengerjakan semua jenis penghitungan. Dengan kata lain, dapat menulis dengan ujung jari, dan MyScript Calculator akan menampilkan hasilnya segera. fitur terbaik dari MyScript Calculator adalah kemampuan menuliskan penghitungan di layar sehingga aplikasi ini lebih mudah dan natural digunakan daripada kalkulator standar. Namun itu bukan satu-satunya kehebatan aplikasi ini. Selain operasi dasar seperti penambahan, pengurangan, dan perkalian, Anda juga dapat melakukan penghitungan yang lebih kompleks dengan akar, pangkat, sinus, dan kosinus, dan sebagainya juga dapat mematikan hasil otomatis di MyScript Calculator jika mau karena jika tidak menulis dengan cepat, aplikasi ini mungkin akan menyelesaikannya sebelum mengerjakannya secara manual. MyScript Calculator adalah aplikasi kalkulator luar biasa yang berfokus pada cara pengerjaan soal matematika yang jauh lebih intuitif daripada kebanyakan kalkulator tradisional.
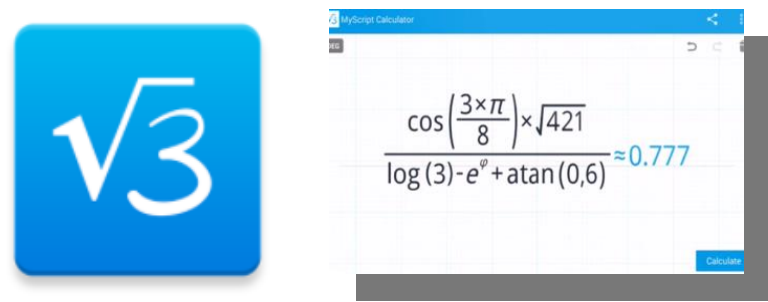

Gambar 6. Software MySript Calculator

Masih banyak lagi software yang dapat digunakan dalam handphone sepert: MyScipt Calculator dan lain sebagainya. Beberapa software telah digunakan dalam pembelajaran matematika. Sebagian besar software matematika digunakan untuk membantu siswa dalam memahami materi matematika. Software tersebut digunakan untuk memvisualisasikan konsep atau fakta serta operasi dalam matematika. Software pada laptop yang telah digunakan dalam matematika, antara lain: (1) GeoGebra, (2) Minitab, (3) SPSS, (4) Visual Basic, (5) Microsoft Excel, (6) POM for Windows, (7) Turbo Pascal, (8) Matlab, dan (9) Maple.

\section{E. Tuntutan Era Revolusi Industri 4.0 bagi Guru Matematika}

Membaca situasi di era Revolusi Industri 4.0, nampak adanya keterkaitan erat antara teknologi dan pembelajaran matematika, maka perlu ada perhatian pada revitalisasi 
pendidikan matematika agar bisa kompetitif di era ini. Pendidikan matematika mestinya berusaha mengakomodasi tuntutan kemampuan yang dibutuhkan di era Revolusi Industri 4.0 yang dinamis agar sesuai dengan perkembangan teknologi. Kondisi ini perlu diperhatikan oleh dunia pendidikan di Indonesia agar segera tanggap terhadap perubahan yang terjadi dan mempersiapkan sumber daya yang dimiliki dalam rangka menghadapi tren Industri 4.0. Singkatnya, untuk bisa bersaing di era Industri 4.0, masyarakat harus mampu membaca dan responsif terhadap perubahan dan membekali diri dengan skill terkini.

Mengutip dari publikasi World Bank pada 2017, Ahmad (2018) berhipotesis bahwa dunia kerja membutuhkan kombinasi berbagai skill yang berbeda dengan skill yang selama ini diberikan oleh sistem pendidikan tinggi. Dosen pun harus mempunyai kompetensi inti yang sesuai dengan kebutuhan Industri 4.0. Menurut World Bank, ada setidaknya 10 skill pekerja yang dibutuhkan oleh penyedia lapangan kerja di era Industri 4.0, yaitu: (1) kebiasaan kerja positif (positive work habits), (2) kepemimpinan (leadership), (3) komunikasi (communication), (4) teknis (technical), (5) menulis (writing), (6) bahasa Inggris (English), (7) pemecahan masalah (problem solving), (8) membaca (reading), (9) komputer (computer), (10) bekerja dalam tim (team work). Bukan hanya dosen, sudah saatnya juga guru matematika seirama dengan perkembangan di era Industri 4.0.

Tidak diragukan lagi bahwa mengajar dan mendidik adalah pekerjaan guru yang tidak semua orang memenuhi syarat atau dapat melakukannya (Ary dkk, 2010), terlebih lagi kalau kita melihat tuntutan skill yang dibutuhkan di era Revolusi Industri 4.0 ini. Ciriciri pokok pekerjaan guru sebagai pekerja profesional, yaitu (1) harus ditunjang oleh suatu ilmu tertentu secara mendalam yang hanya mungkin diperoleh dari lembaga-lembaga pendidikan yang sesuai, yaitu LPTK (Lembaga Pendidikan Tenaga Kependidikan), (2) menuntut adanya keahlian dalam mengajar dan mendidik, (3) berhak memperoleh penghargaan yang layak sesuai tingkat keahlian yang dimiliki, dan (4) selain dibutuhkan oleh masyarakat, juga akan memberi dampak terhadap kehidupan sosial kemasyarakatan, sehingga masyarakat memiliki kepekaan yang sangat tinggi terhadap efek yang ditimbulkan oleh pekerjaan profesi itu (Sanjaya, 2005).

Sejalan dengan itu, guru mempersiapkan generasi masa depan yang handal dan berkualitas. Karena itulah, pekerjaan guru berupa mendidik dan mengajar bukan pekerjaan yang bersifat statis, melainkan bersifat dinamis, artinya selalu harus dapat menyesuaikan diri dengan perkembangan ilmu pengetahuan dan teknologi. Dengan demikian, guru dituntut untuk peka terhadap dinamika perkembangan yang terjadi di masyarakat, baik perkembangan kebutuhan yang juga bersifat dinamis, maupun perkembangan sosial, budaya, politik, dan teknologi.

Agar seorang guru, khususnya guru matematika dapat memenuhi harapan seperti diuraikan di atas, maka guru harus memiliki 4 kompetensi yang memadai, yaitu kompetensi profesional, kompetensi pedagogik, kompetensi kepribadian, dan kompetensi sosial. Dalam melaksanakan tugasnya sebagai guru matematika di kelas, guru dituntut untuk menampilkan kinerjanya secara maksimal melalui perwujudan dari keempat kompetensi tersebut secara simultan.

Masalah baru yang timbul dan harus dijawab oleh guru matematika adalah bagaimana seharusnya ia menunjukkan kinerjanya yang memadai berdasarkan keempat kompetensi itu di era Revolusi Industri 4.0 saat ini? Sebagai contoh, misalnya seorang guru matematika akan mengajarkan tentang topik "Sudut dan Garis" kepada para siswanya. Salah satu unjuk kerja minimal yang perlu ditampilkan agar ia dapat dianggap mengajar secara profesional di era Revolusi Industri 4.0 saat ini dapat digambarkan seperti berikut ini. 


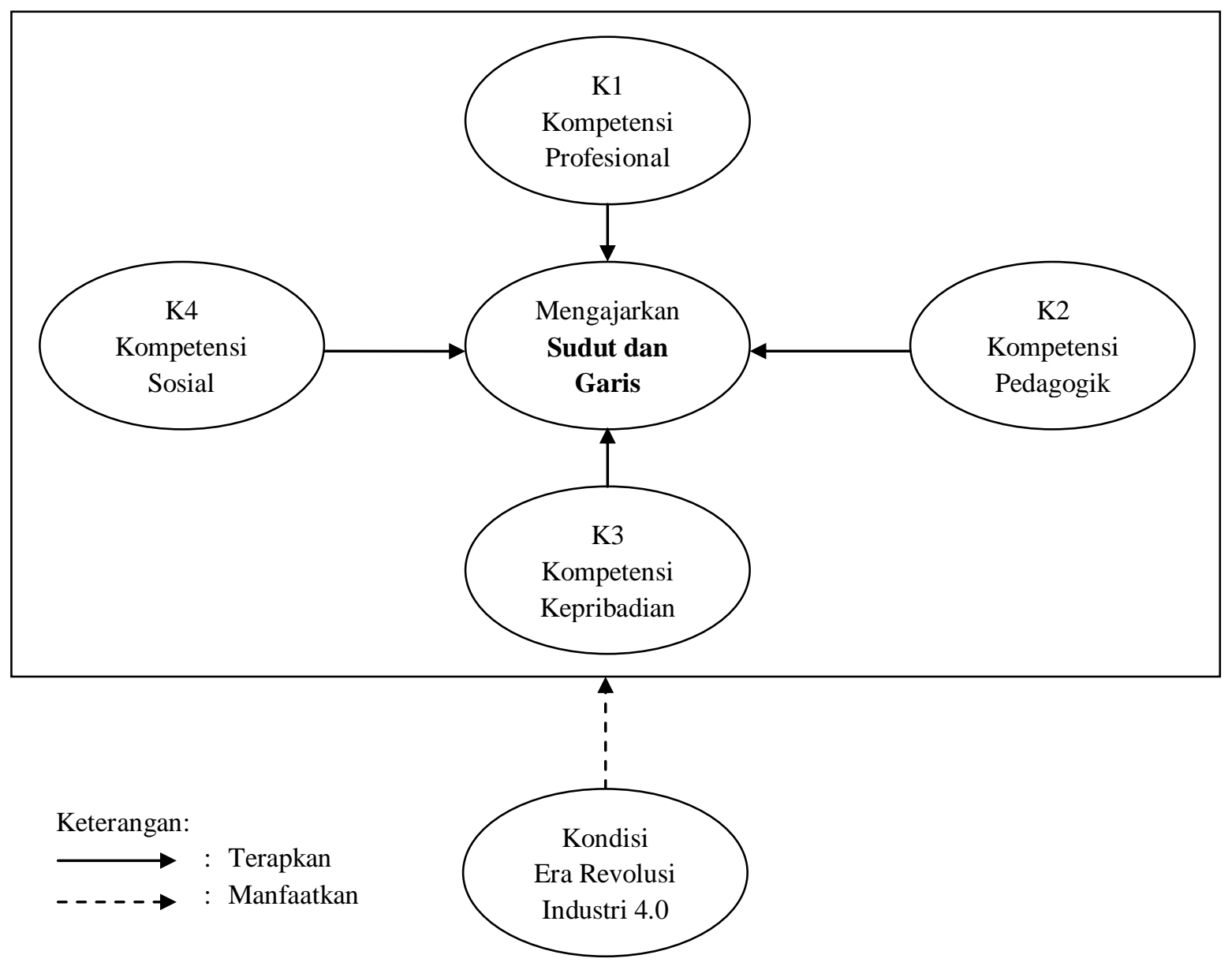

\section{K1: Kompetensi Profesional}

1. Kuasai materi sudut dan garis, meliputi:
a. Konsep sudut dan garis
b. Konsep pengukuran sudut dan garis
c. Konsep satuan sudut
d. Konsep tentang jenis-jenis sudut
e. Aksioma-aksioma tentang sudut dan garis
f. Teorema-teorema atau sifat-sifat tentang sudut dan garis
g. Pemecahan masalah kontekstual yang menggunakan sudut dan atau garis

2. Sejarah tentang munculnya konsep sudut dan garis

3. Manfaat mempelajari sudut dan garis, baik terhadap matematika itu sendiri, maupun terhadap mata pelajaran lain, seperti fisika, kimia, biologi, sosial, dan sebagainya

4. Wawasan lain yang mempunyai hubungan dengan sudut dan garis

\section{K2: Kompetensi Pedagogik}

1. Buatlah Perangkat Pembelajaran dan instrumen yang baik tentang sudut dan garis, meliputi:
a. RPP
b. LKPD/LKS
c. Tes Hasil Belajar 


\section{d. Lembar bahan ajar}

2. Terapkan model/strategi/metode/teknik/siasat/taktik pembelajaran yang sesuai dengan topik sudut dan garis

3. Terapkan/manfaatkan teknologi yang tepat yang mendukung pencapaian tujuan pembelajaran tentang sudut dan garis, di sini secara khusus dapat digunakan satu atau beberapa produk teknologi di Era Revolusi Industri 4.0 (seperti telah disebutkan beberapa jenis produk teknologi di halaman sebelumnya)

4. Lakukan Penelitian Tindakan Kelas atau manfaatkan hasil PTK guru lain tentang pembelajaran sudut dan garis

5. Kuasai dan terapkan evaluasi yang cocok untuk pembelajaran sudut dan garis meliputi:

a. Buatlah dan terapkan instrumen asesmen autentik tentang sudut dan garis

b. Buatlah dan terapkan tes hasil belajar yang cocok untuk topik sudut dan garis, baik tertulis maupun tak tertulis (tes kinerja, portofolio, proyek, dan sebagainya)

\section{K3: Kompetensi Kepribadian}

1. Jadilah guru yang dapat menjadi teladan bagi para siswa dalam hal beribadah kepada Allah subhanahu wata'ala (cara berdo'a, bersyukur, sabar, ikhtiar) dalam melaksanakan pembelajaran di kelas, termasuk dalam mengajarkan sudut dan garis. Angkatlah satu atau beberapa contoh ayat-ayat dan tanda-tanda kekuasaan Allah subhanahu wata'ala yang terkait dengan sudut dan garis. Sebagai contoh, "aksioma tentang garis lurus" yang otomatis benar secara matematis, yaitu "Jika A dan B dua titik yang berbeda, maka hanya ada satu garis lurus yang dapat dibuat melalui A dan B". Hubungannya dengan kehidupan pribadi yang terkait dengan ajaran agama (akidah) adalah kalau $D$ titik yang melambangkan Dunia dan A titik yang melambangkan Akhirat, maka hanya ada satu jalan lurus dari $D$ ke A. Adapun yang tidak lurus tak terhingga banyaknya.

2. Jadilah guru yang menyenangkan dan tegas secara pribadi, berperilaku terpuji, misalnya jujur, adil, obyektif, disiplin, menyayangi siswa, taat aturan, dan sebagainya.

3. Berpenampilan menarik dalam mengajar, baik secara fisik maupun nonfisik, selalu nampak simpatik, antusias, dan tidak membosankan. Berusahalah semaksimal mungkin untuk membuat anak/peserta didik terkesan pada saat Anda mengajar, sehingga seolaholah ada kalimat dari peserta didik yang bernada, "Kapan lagi Bapak/Ibu masuk mengajar?" hindari kalimat yang bernada "Kenapa Bapak/Ibu lagi yang masuk mengajar?"

4. Tumbuhkembangkan akhlak terpuji, sifat-sifat dan kebiasaan-kebiasaan positif dalam melaksanakan tugas, termasuk tidak kikir memberi penghargaan dan pujian terhadap peserta didik yang memiliki kelebihan.

\section{K4: Kompetensi Sosial}

1. Bantulah peserta didik pada saat mereka membutuhkan, terutama dalam hal pemberian bimbingan dan petunjuk dalam proses pembelajaran.

2. Bangun suasana interaksi yang harmonis dan menyenangkan dalam kelas, sehingga terjadi kerjasama yang diharapkan.

3. Berikan dorongan kepada peserta didik agar mereka dapat saling bantu membantu, tolong menolong, saling menghargai, dan saling peduli, tentu saja dalam hal-hal yang bersifat positif, baik dalam suasana pembelajaran, maupun diluar kelas.

Dengan menerapkan berbagai aspek pada empat kompetensi di atas, berarti peran guru dalam proses pembelajaran dapat dianggap terpenuhi, yaitu guru sebagai fasilitator, sumber 
belajar, manajer, demonstrator, administrator, motivator, organisator, inspirator, dinamisator, inovator, dan evaluator.

\section{F. Penutup}

Perkembangan ilmu pengetahuan yang seiring dengan keinginan manusia melakukan inovasi dapat dianggap sebagai pemicu timbulnya Revolusi Industri dari masa ke masa, dari Revolusi Industri 1.0 hingga Revolusi Industri 4.0. Tiap era revolusi Industri memiliki peluang dan ancaman. Khusus era Revolusi Industri 4.0 atau era globalisasi bagi Indonesia, masyarakat harus mampu membaca dan responsif terhadap perubahan dan membekali diri dengan keterampilan terkini. Bagi Indonesia khususnya, masyarakat harus mampu membaca dan responsif terhadap perubahan dan membekali diri dengan keterampilan terkini agar bisa bersaing. Di era ini, realitas menunjukkan bahwa teknologi dan pembelajaran matematika memiliki kaitan erat. Pemanfaatan teknologi dengan baik dalam pembelajaran akan memberi penguatan terhadap pola perubahan paradigma pembelajaran. Sifat abstrak objek kajian matematika yang sulit dipikirkan oleh peserta didik dapat dipresentasikan melalui simulasi komputer agar lebih konkrit. Latihan dan percobaan eksploratif matematika dapat dilakukan peserta didik dengan menggunakan program komputer atau software matematika untuk penanaman dan penguatan konsep, membuat pemodelan matematika, dan menyusun strategi dalam memecahkan masalah. Oleh karena itu, guru matematika dituntut agar seirama dengan perkembangan di era ini.

\section{REFERENSI}

Aoun, J.E. (2017). Robot-proof: higher education in the age of artificial intelligence. US: MIT Press.

Ary, D., Jacobs, L. C., Sorensen, C. K., \& Razavieh, A. (2010). Introduction to Research in Education. USA: Wadsworth Cengage Learning.

Drath, R., \& Horch, A. (2014). Industrie 4.0: Hit or hype? [industry forum]. IEEE industrial electronics magazine, 8(2), pp. 56-58.

Irianto, D. (2017). Industry 4.0: The Challenges of Tomorrow. Disampaikan pada Seminar Nasional Teknik Industri, Batu-Malang.

Iswan \& Herwina. (2018). Penguatan Pendidikan Karakter Perspektif Islam dalam Era Millenial IR. 4.0. Prosiding Seminar Nasional Pendidikan Era Revolusi "Membangun Sinergitas dalam Penguatan Pendidikan Karakter pada Era IR 4.0", Hal. 21-42.

Kuntowijoyo. (2006). Islam sebagai Ilmu: Epistemologi, Metodologi, dan Etika. Yogyakarta: Tiara Wacana. 
Prasetyo, H. \& Sutopo, W. (2017). Perkembangan Keilmuan Teknik Industri Menuju Era Industri 4.0. Prosiding Seminar dan Konferensi Nasional IDEC 2017, hal. 488-495. . (2018). Industri 4.0: Telaah Klasifikasi Aspek dan Arah Perkembangan Riset. J@ti Undip: Jurnal Teknik Industri, Vol. 13(1): 17-26.

Sanjaya, W. (2005). Pembelajaran Implementasi Kurikulum Berbasis Kompetensi. Jakarta: Kencana Prenada Group.

Yahya, M. (2018). Era Industri 4.0: Tantangan Dan Peluang Perkembangan Pendidikan Kejuruan Indonesia. Pidato Pengukuhan Penerimaan Jabatan Professor Tetap dalam Bidang Ilmu Pendidikan Kejuruan Fakultas Teknik Universitas Negeri Makassar, yang Disampaikan pada Sidang Terbuka Luar Biasa Senat Universitas Negeri Makassar Tanggal 14 Maret. 